\title{
A CONCEPTUAL FRAMEWORK FOR ANALYSING AND PROMOTING COMPETITIVENESS IN THE MARITIME INDUSTRY IN LESS-FAVOURED REGIONS
}

\author{
ARMAND DJOUMESSI MOUAFO \\ Division of Research Services, University of Tasmania, Australia \\ *Corresponding author: armand.mouafo@utas.edu.au
}

http://doi.org/10.46754/jml.2021.08.006

\begin{abstract}
Like other economic activities, maritime businesses are unevenly distributed across the globe and tend to concentrate in large metropolitan agglomerations, often more associated with innovation. As a result, conceptual approaches for promoting competitiveness through innovation are mostly tailored to their characteristics. The predominant approach has been the concept of clusters, a prominent concept in maritime research. The limitations of the application of the clusters approach for less-favoured (non-metropolitan) regions have been pointed out and have prompted calls for alternative approaches better suited for these types of regions, where innovation is even more crucial. Drawing inspiration from available economic geography literature, this paper proposes the concept of constructing regional advantage (CRA) as an approach for promoting competitiveness through continuous innovation in the maritime context in less-favoured regions.
\end{abstract}

Keywords: Less-favoured regions, maritime industry, CRA framework, innovation, industrial competitiveness.

\section{Introduction}

The contribution of the maritime industry to the economic prosperity of nations and regions (in the sense of subnational territorial units) is well established in academic and policy debates (Ding, Ge, \& Casey, 2014; Morrissey, O’Donoghue, \& Farrell, 2014). Therefore, policymakers around the world are interested in strategies aimed at improving the competitiveness of their respective maritime industries. Though what constitutes the maritime industry varies not just from country to country but between one scholar and another (Ding et al., 2014; Doloreux \& Melançon, 2008), the sectors of activities often targeted by these strategies are can be broadly categorised into maritime manufacturing, maritime transportationoriented services, offshore-oriented maritime services, and advanced maritime producer services (Doloreux \& Melançon, 2008; Isaksen, 2009; Jacobs, Koster, \& Hall, 2011).

Evidence of maritime competitiveness strategies at the supranational level include the European Commission's 2006 Maritime
Policy Green Paper (Salvador, 2013). While, the Chinese Government's 2007 and 2008 marine development strategies, as well as its emphasis on the need to strengthen maritime competitiveness in the 12th Five-Year (20112015) Chinese National Economic and Social Development Plan (Yan, Yan, Yao, \& Liao, 2015) is a national level example. At the regional level, examples include the European Commission's 2013 Atlantic Action Plan (Pinto, Cruz, \& Combe, 2015), Quebec's 2015 Maritime Strategy (Doloreux, Shearmur, \& Figueiredo, 2016) and various Chinese provinces' maritime strategies (Ding et al., 2014). These regional strategies highlight the importance of regions in the economic prosperity of nations. It has been argued by Coe, Hess, Yeung, Dicken, and Henderson (2004), Carlsson (2007) and O'Riain (2011) that in today's era of a global knowledge economy, regions are the key level at which innovative capacity is shaped and governed.

To promote regional industrial competitiveness through innovation, policymakers have and continue to rely on frameworks developed mainly by economic geographers and business 
economists, the most influential of which are clusters (Porter, 2000), and to a lesser extend regional innovation systems (RIS) (Cooke, Gomez Uranga, \& Etxebarria, 1997). While clusters are "geographic concentrations of interconnected companies and institutions in a particular field" (Porter, 1998), a RIS can be either broadly or narrowly defined. From a narrow perspective, a RIS is "the institutional and organisational infrastructure interacting and supporting innovation within the production system of the region" (Asheim, Coenen, \& Moodysson, 2015). Broadly viewed, a RIS includes all the actors affecting and influencing learning and innovation in a region (Asheim, 2012). Recent empirical findings suggest that the effectiveness of these frameworks is influenced by regional characteristics (Isaksen \& Sæther, 2015; Melançon \& Doloreux, 2013). By implication, attention should be paid to the location dimension when choosing an industrial competitiveness approach (Doloreux et al., 2016; Malmberg \& Maskell, 2006).

In terms of their innovative capabilities, regions have been categorised into peripheral, old industrial and metropolitan regions which can either be fragmented or connected (European Commission, 2006; Tödtling \& Trippl, 2005). It is important here to understand that peripheral regions are equated to nonmetropolitan regions, which have also been referred to as small regions by Isaksen and Karlsen (2013). The common factor underlying these terminologies is that these regions are located outside major metropolitan regions and clusters, and less endowed in innovation prerequisites such as population, research and development (R\&D) intensity, knowledge infrastructures (universities and institutes) and innovative firms. For these reasons, they have been referred to as thin regions (Isaksen, 2014; Tödtling \& Trippl, 2005).

Fragmented metropolitan regions, though endowed with innovation prerequisites are deficient in terms of innovative networks and interactions between universities and firms, as well as among local companies. As a result, they generally end-up as old industrial regions, which are trapped in negative lock-ins and often end-up as non-metropolitan regions. Connected metropolitan regions, however, are innovative regions with the best precondition endowments that through continuous innovation avoid lock-ins. These regions have received greater attention in the innovation literature, mainly because existing innovation frameworks fit for their analysis, and host high-tech/knowledge intensive industries that are often the focus of innovation studies (Doloreux \& Melançon, 2008; Isaksen \& Karlsen, 2013).

There is however a need to understand innovative processes in non-metropolitan regions, which face greater challenges to innovation (Rodríguez-Pose \& Fitjar, 2013). Similarly, there is a need for innovation research in other types of industries. In particular, less attention has been paid to innovative activities in the maritime industry - one of the leading industries in the current area of globalisation (Bass \& Ernst-Siebert, 2007; Yan et al., 2015), especially on innovative practices of maritime firms at the non-metropolitan level (Doloreux, 2006; Doloreux \& Melançon, 2008).

Understanding and planning innovation in non-metropolitan regions however requires appropriate frameworks. A consequence of the concentration of innovation research in metropolitan regions is that clusters and RIS approaches to innovation are modelled on such regions. Recent empirical studies such as Melançon and Doloreux (2013) and Doloreux et al. (2016) however suggest that these frameworks present severe limitations when used as tools for analysing and planning innovation in the maritime industry in nonmetropolitan regions. The reason is that they are modelled on the principles of agglomeration economies such as knowledge spillovers through labor mobility, which are less relevant in nonmetropolitan regions (Isaksen \& Karlsen, 2013). These limitations have led Melançon (2011) to call for alternative approaches to innovation and competitiveness in non-metropolitan regions. 
This paper responds to the above call by Melançon (2011). Building on the economic geography concept of constructing regional advantage (CRA), the purpose of this paper is to propose a comprehensive framework to analyse and promote innovation in the maritime industry in non-metropolitan regions.

The remainder of the paper is organised as follows. Section 2 examines the relationship between location and innovation. Section 3 identifies the research gaps in the current literature on maritime clusters/RIS approaches to competitiveness in non-metropolitan regions. Section 4 addresses these research gaps in terms of the CRA approach and proposes an extension of this approach. Section 5 provides the conclusions to the paper including an agenda for the operationalisation of the framework in the maritime industry.

\section{Location and Innovation}

There is widespread agreement in the literature that a consequence of globalisation on regions has been their exposure to extra-regional competition (Camagni, 2002; Karlsen, Isaksen, \& Spilling, 2011). According to Pike, RodríguezPose, and Tomaney (2006), even the most remote spaces are not exempt from globalisation induced competition and are being forced to adjust to new economic conditions. It has been argued by Asheim, Moodysson, and Tödtling (2011) that continuous innovation, driven by knowledge is the only sustainable alternative for developed high-cost country regions to remain competitive in the globalising knowledge economy. Some of these regions are however more equipped than others to respond to the globalisation challenges in terms of innovation preconditions endowments as discussed above, which are influenced by geography (Maskell \& Malmberg, 1999; Shearmur, 2012).

Although recent advances in information and communication technology have undoubtedly eased interactions between distant economic actors, which can result in innovation (Friedman, 2005), the co-location of businesses, knowledge organisations, institutions and workers in geographical proximity facilitate the diffusion not only of codified knowledge, but most importantly of tacit knowledge, which triggers innovation and competitiveness (Malmberg \& Maskell, 2002). The process of globalisation has enhanced the geographical concentration of companies, institutions and human capital in metropolitan regions and this trend is expected to continue (Rodríguez-Pose \& Fitjar, 2013). Evidence can be seen for example, in the maritime industry, as large maritime centres are often found in cities (Verhetsel \& Sel, 2009). The concentration of the maritime port sector in world global cities particularly stands out (Jacobs, Ducruet, \& de Langen, 2010; Merk, 2013). The concentration of economic activities results in knowledge spillovers in the form of either Marshall-Arrow-Romer externalities between firms in similar sectors, Jacobian externalities between firms in different sectors or urbanisation externalities (Glaeser, Kallal, Scheinkman, \& Shleifer, 1992) resulting from urban size and density. The combination of these externalities in metropolitan regions stimulate formal and informal face-to-face exchanges often called buzz (Bathelt, Malmberg, \& Maskell, 2004), which promote the generation and diffusion of innovations. Such innovations in metropolitan regions foster entrepreneurial activities, which lead to the formation of new firms (Boschma, 2013). This attracts labour, which might have become redundant due to productivity increases or demand saturation from non-metropolitan regions, further increasing concentration in metropolitan regions (Florida, Gulden, \& Mellander, 2008; Frenken, Van Oort, \& Verburg, 2007).

Knowledge spillovers generated in metropolitan regions however, decay with distance. It has empirically been found that they become irrelevant after $80 \mathrm{~km}$ in the US (Acs, 2002; Varga, 2000) and $250 \mathrm{~km}$ in European regions (Moreno, Paci, \& Usai, 2005) from their point of origin respectively. The type of region also determines the type of firms present, which in turn determines the type of activities carried out(Isaksen, 2014; McCann, 2008). For example, 
it can be inferred from Verhetsel and Sel (2009) that world maritime cities, from which container shipping companies make major administrative decisions shaping the shipping industry, are all metropolitan cities. Similarly, Hall and Jacobs (2012) contend that maritime ports are still urban despite recent transformations in the maritime industry brought about by globalisation.

According to McCann (2008), knowledge intensive activities that foster innovations are mostly carried out in increasing return to scale environments associated with metropolitan regions, while low knowledge-intensive activities are often associated with non-metropolitan regions. This argument is corroborated by Jacobs et al. (2011), from whose study it can be inferred that providers of advanced maritime producers services (AMPS) are primarily located in urban environments. Implicitly, larger companies are more likely to be in metropolitan regions with greater demand, while non-metropolitan regions are characterised by the dominance of small and medium size enterprises (SMEs). For example, the study by Doloreux (2006) on regional innovation in the maritime industry shows that most of the maritime firms in non-metropolitan Quebec are SMEs. SMEs often have limited research and development (R\&D) resources and therefore tend to innovate incrementally (European Commission, 2006; Isaksen, 2014).

It can be inferred from the above discussion that innovation is more likely to be created and contained within large agglomerations. The innovation handicaps of non-metropolitan regions can also relate to the lack of critical mass of economic actors, human capital, knowledge organisations and institutions to generate spillovers benefits, as well as to their distance from innovation centres. Therefore appropriate frameworks are needed in order to promote innovation in these regions (Melançon, 2011).

It will be misleading however to assume that other forms of proximities (cognitive, social, institutional, organisational) (Boschma, 2005) are not necessary for innovation, or that businesses located in non-metropolitan regions do not innovate (Fitjar \& Rodríguez-Pose, 2011a). The key argument being made is that non-metropolitan regions face greater challenges to innovation, and that influential theoretical approaches to innovation promotion (clusters and RIS) have been developed with metropolitan regions in mind, and therefore are less relevant for these regions. Several authors have critically analysed the impact of these frameworks on regional competitiveness, in the context of the maritime industry in non-metropolitan regions. The next section reviews this literature.

\section{Maritime Cluster/RIS Approaches to Regional Competitiveness}

The concept of clusters and RIS are influential analytical tools that have received significant attention from maritime scholars. In accordance with Doloreux et al. (2016), the maritime clusters/ RIS literature can be broadly categorised into three groups. The first group describes the actors and institutional arrangements for maritime clusters/RIS (Brett \& Roe, 2010; Chang, 2011; Monteiro, 2015; Morrissey \& O’Donoghue, 2013; Ortega, Nogueira, \& Pinto, 2013; Othman, Bruce, \& Hamid, 2011). The second group is concerned with the effects of clusters/RIS dynamics on the innovative activities of maritime firms (Benito, Berger, De la Forest, \& Shum, 2003; de Langen, 2002; Doloreux \& Melançon, 2008; Makkonen, Inkinen, \& Saarni, 2013; Pinto et al., 2015). The third group relates to maritime clusters/RIS approaches to competitiveness in the maritime industry, and by extension the region where maritime activities are located (Ding et al., 2014; Doloreux \& Melançon, 2009; Doloreux et al., 2016; Flitsch, Herz, Wolff, \& Baird, 2014; Melançon \& Doloreux, 2013; Merk \& Dang, 2013; Pinto \& Cruz, 2012), or even the country as a whole (Salvador, 2013; Shinohara, 2010).

As already mentioned, this paper is primarily concerned with conceptual approaches used to promote innovation in the maritime industry in non-metropolitan regions. Therefore, in line with its purpose, the review focuses on the third group, specifically focusing on the sub-national level. The peer-reviewed articles relevant to 
this third group are summarised in Table 1, and further discussed below.

The effect of cluster/RIS approaches have extensively been studied in the context of the non-metropolitan region of Quebec's Coastal region (QCr) (Canada), and five of the seven relevant articles directly dealing with the subject matter relate to this region. Doloreux and Shearmur (2006) assess the effectiveness of a clusters policy as tool for promoting employment growth through innovation in the maritime in QCr. Following their analysis, they contend that from a theoretical standpoint, the clusters approach, which is built on assumptions of proximity between regional actors and principles of agglomeration economies, is inappropriate for QCr.

On the effect of maritime cluster policy on employment growth in the maritime industry in QCr, Doloreux et al. (2016) look at the effect of a maritime cluster approach to employment growth on various maritime sectors over a ten year-period (2001-2011). In addition, they compare employment growth in sectors related to QCr's maritime cluster and the rest of Quebec and assess whether occupations in maritime sectors have become more science- inclined. They conclude that the maritime cluster approach has had only a marginal effect on Quebec's local economy and on the sectors targeted.

Using a set of case studies involving semistructured interviews, Doloreux and Melançon (2009) examine the role of three innovationsupport organisations in the marine science and technology industry in QCr. The marine science and technology industry is a component of the QCr's maritime industry (Doloreux \& Melançon, 2008; Doloreux et al., 2016). These innovation-support organisations are involved in the acquisition and diffusion of technological ideas, solutions and know-how in the marine science and technology innovation system. The rationale for the development of these organisations is based on the RIS approach, the narrow perspective, and they represent the knowledge production and diffusion subsystem. They were developed in anticipation that their activities will stimulate regional innovation through knowledge spillovers and the formation of new industries. Doloreux and Melançon (2009) conclude after their study that, although innovation-support organisations have played a key role in the production and diffusion of know-how, the results have been hindered by regional characteristics, including the lack of critical mass of researchers as well as that of firms able to utilise the innovation produced.

Melançon and Doloreux (2013) examine the effectiveness of the narrow view of the RIS approach, through the development of knowledge infrastructures, as a tool for analysing and planning innovation development in the maritime industry in QCr. Their study is similar to that of Doloreux and Melançon (2009), with the addition of including eighteen supports organisations as follows: three higher education institutes, two public research institutes, nine technology transfer organisations, one vocational training organisation and three others. A key finding of their study is that developing a regional knowledge production subsystem without increasing the absorptive capacity of regional maritime firms leads to a marginal effect on regional industrial competitiveness.

In addition to examining the driving forces and the development of three Canadian maritime clusters (QCr, St. John, and British Columbia), Doloreux and Shearmur (2009) also discuss the role of cluster policy in promoting maritime industrial competitiveness in these Canadian regions. Regarding their second objective, these authors found that a maritime cluster approach to innovation has not led to significant increase in the innovative activities of maritime firms. They argue that maritime cluster approaches to industrial competitiveness, and by extension regional competitiveness can only lead to marginal results in non-metropolitan regions lacking agglomerations economies. Similarly, they contend that though local buzz and networking might benefit firms in remotes areas, they need not to be exclusively regional in nature. 
Flitsch et al. (2014) do not directly deal with a specific region but their conclusion regarding the approach to cluster development and implementation is particularly relevant, as top-down policies ignoring regional specificities and developed without regional stakeholders' consultation are most likely to fail (Boschma, 2014). Similarly, Ding et al. (2014) do not explicitly refer to RIS and do not discuss regional characteristics but he investment strategies of Chinese regions follow this approach, through the development of knowledge infrastructure. Furthermore, although Djoumessi, Chen, and Cahoon (2019) do not specially emphasise the type of region, they demonstrate that irrespective of location, strategies for promoting innovation in the maritime industry should incorporate measures to develop the internal innovative capabilities of firms.

A key outcome of the above review is that maritime clusters/RIS approaches to regional competitiveness, though appealing to regional policymakers (they have been and continue to be used as competitiveness approaches) in nonmetropolitan regions, have a marginal effect on regional industrial innovation and employment growth. Consequently, subsequent attempts to use these frameworks should consider regional specifics.

Table 1: Literature related to maritime clusters/RIS approaches to regional competitiveness

\begin{tabular}{|c|c|c|c|c|c|}
\hline $\begin{array}{c}\text { Author (s) } \\
\text { (year) }\end{array}$ & Journal & Purpose & Conclusions & $\begin{array}{c}\text { Framework } \\
\text { used }\end{array}$ & $\begin{array}{l}\text { Region/ } \\
\text { Country }\end{array}$ \\
\hline $\begin{array}{l}\text { Melançon } \\
\text { and } \\
\text { Doloreux } \\
(2013)\end{array}$ & $\begin{array}{c}\text { Regional } \\
\text { Studies }\end{array}$ & $\begin{array}{l}\text { Analyse the effectiveness } \\
\text { of the RIS approach as a } \\
\text { tool to analyse and plan } \\
\text { innovation development } \\
\text { in the periphery. }\end{array}$ & $\begin{array}{l}\text { Well-developed knowl- } \\
\text { edge infrastructures } \\
\text { (knowledge produc- } \\
\text { tion subsystem) do not } \\
\text { automatically lead to } \\
\text { the development com- } \\
\text { petitive regional pro- } \\
\text { duction subsystem. }\end{array}$ & $\begin{array}{c}\text { RIS - Narrow } \\
\text { view }\end{array}$ & $\mathrm{QCr} /$ Canada \\
\hline $\begin{array}{l}\text { Ding et al. } \\
\text { (2014) }\end{array}$ & $\begin{array}{l}\text { Marine } \\
\text { Policy }\end{array}$ & $\begin{array}{l}\text { Analysis of the } \\
\text { competitiveness of } \\
\text { the maritime industry } \\
\text { along the eastern cost } \\
\text { of China }\end{array}$ & $\begin{array}{l}\text { Continued invest- } \\
\text { ments in the regional } \\
\text { maritime industry will } \\
\text { likely lead to regional } \\
\text { growth but attention } \\
\text { should consider envi- } \\
\text { ronmental issues. }\end{array}$ & $\begin{array}{l}\text { RIS - Narrow } \\
\text { view (to a } \\
\text { lesser extent) }\end{array}$ & $\begin{array}{l}\text { Shandong, } \\
\text { Zhejiang, } \\
\text { Fujian, } \\
\text { Guangdong } \\
\text { and Jiangsu/ } \\
\text { China }\end{array}$ \\
\hline $\begin{array}{l}\text { Djoumessi } \\
\text { et al. (2019) }\end{array}$ & $\begin{array}{l}\text { Marine } \\
\text { Policy }\end{array}$ & $\begin{array}{l}\text { Identify the factors } \\
\text { influencing innovation } \\
\text { in maritime clusters }\end{array}$ & $\begin{array}{l}\text { To promote innovation } \\
\text { in maritime clusters, } \\
\text { clusters policies } \\
\text { should also include } \\
\text { firm level strategies }\end{array}$ & Clusters & $\begin{array}{c}\text { Perth } \\
\text { Metropolitan } \\
\text { region and } \\
\text { Tasmania/ } \\
\text { Australia }\end{array}$ \\
\hline
\end{tabular}




$\begin{array}{ll}\text { Doloreux } & \\ \text { and } & \text { Marine } \\ \text { Shearmur } & \text { Policy } \\ \text { (2009) } & \end{array}$

Doloreux et al. (2016)

Flitsch et al. (2014) Maritime Economics \& Logistics
Marine

Policy

\section{Melançon and \\ Doloreux} (2013)

Ding et al. Marine (2014) Policy
Examine the driving force and the development processes of different maritime clusters and the role of clusters policy in maritime competitiveness promotion and the key institutional and geographic barriers that affect their growth and development.

Examine the stages of development of clusters policy.
Analyse the effectiveness of the RIS approach as a tool to analyse and plan innovation development in the periphery.

Analysis of the competitiveness of the maritime industry along the eastern cost of China
No significant increase in innovative because of clusters policy. The region's size, the level of agglomeration already present, its proximity to major agglomeration centres conditions the effectiveness of clusters policies. Local buzz necessary to innovation should not be exclusively focused on regional actors.

The cluster has had only a marginal effect on employment resources risk being wasted given the amount of investment in cluster approaches.

Clusters policies will benefit regions if developed through publicprivate partnerships, in addition to following a bottom-up approach.

Well-developed knowledge infrastructures (knowledge production subsystem) do not automatically lead to the development competitive regional production subsystem.

Continued investments in the regional maritime industry will likely lead to regional growth but attention should consider environmental issues.
Clusters QCr/Canada

Clusters

\section{North- Sea}

region

RIS -

Narrow

QCr/Canada

view

RIS Shandong, Narrow view (to a lesser extent)
Labrador and Newfoundland

British

Columbia/

Canada 
It is now well established that maritime clusters/RIS approaches to innovation in nonmetropolitan regions have only produced marginal results. The logical question therefore is: What is the alternative ? Though current studies conclude that the current approaches are inappropriate, they fail to provide an alternative approach, leaving regional policymakers with no viable option. This paper goes a step further in the following section to provide such an alternative.

\section{An Alternative Approach for Promoting Regional Competitiveness in the Maritime Industry}

The alternative proposed in this paper is another economic geography concept, namely the CRA approach to regional competitiveness (Asheim, Boschma, \& Cooke, 2011; Asheim, Moodysson, \& Tödtling, 2011; European Commission, 2006). This section first discusses its rationale and its links to clusters and RIS approaches, followed by its innovation enablers (building blocks). Its limitations are subsequently discussed. The section ends with a proposed reconceptualisation of the CRA approach.

\section{CRA Rationale And Definition}

According to Boschma (2014), the CRA concept was developed when the limitations of technology and innovation policy that had been, and continue to overemphasise a research and development (R\&D) driven approach to innovation had become apparent. It has been argued by Hansen and Winther (2011) that such an approach increases interregional inequalities because high-tech industries are predominantly located in metropolitan regions, which are major beneficiaries of $R \& D$ policies. The approach has also been criticized for being inclined towards the science push model of innovation characterised by basic and applied research, product and process development, production, marketing and diffusion (Doloreux, 2002). Following recent work on innovation systems (Asheim et al., 2015; Martin \& Trippl, 2014), there is now widespread agreement that innovation is an interactive learning process combining science, technology, innovation (STI), and doing, using, interacting (DUI) modes of innovation (Asheim, 2012). Similarly, Porter (1990) contends that the unique resources allowing companies to innovate need not be $\mathrm{R} \& \mathrm{D}$, rendering the distinction between low and high regions irrelevant.

The CRA approach therefore adopts Porter's (2000) view that all industries can be innovative, and for a high cost country, competitiveness in the globalisation knowledge economy is achieved through product differentiation and cost efficiency, a view also shared by Asheim, et al., (2007). It however differs from Porter's (2000) view by building on the innovation system approach (Lundvall, 2008) to explain how innovation develops with regard to the public sector's role in innovation. While Porter $(2003 ; 2000 ; 1990)$ argues that innovation is predominantly market driven and occurs because of companies being co-located in geographical entities called clusters, the innovation system approach contends that innovation occurs through an interactive learning process (between the knowledge production and exploitation structures) and that competitiveness is enhanced by innovation policy. Consequently, CRA advocates "a stronger role of government and public policies in initiating public-private collaborations in the promotion of innovation and competitiveness" (Asheim, Moodysson, \& Tödtling, 2011). Following from this, CRA means turning comparative advantage into competitive advantage through an explicit policy push promoting a Chamberlinian monopolistic competition based on product differentiation creating unique products, an assumption which was fundamental for Porter's cluster approach also (Asheim, Moodysson, \& Tödtling, 2011). With this definition and rationale in mind, one might ask what its innovation enablers are. The next section explains the building blocks of CRA. 


\section{The CRA Building Blocks}

Central to the CRA framework is that advantage through innovation does not automatically occur when similar or related industries are co-located in the same region. Rather, it must be pro-actively constructed through policy. There is however no one size fits all approach to promoting innovation for all types of regions (Tödtling \& Trippl, 2005). Thus, policy tools should be fine-tuned to regional specificities. Four innovation enablers, constitute its building blocks when adapting policy: the knowledge base/innovation mode, the RIS, related variety, and knowledge sourcing (Karlsen et al., 2011).

The knowledge base approach can be traced back to Laestadius (1998) and has been further expanded on by Asheim and Coenen (2005), Martin and Moodysson (2011) and Manniche, Moodysson, and Testa (2016). The key idea here is that innovation policy should be tailored to a firm's dominant mode of innovation (Asheim, Boschma, \& Coenen, 2011; Jensen, Johnson, Lorenz, \& Lundvall, 2007). A synthetic knowledge base refers to firms dominated by STI while a synthetic knowledge base refers to firms dominated by DUI. Isaksen and Karlsen (2012) have used the term complex, combined innovation (CCI) to characterise firms using both STI and DUI modes of innovation.

A symbolic knowledge base on the other hand refers to companies involved in the artistic and cultural industry using signs and aesthetic symbols to innovative. It has been proven empirically that firms combining knowledge bases are more innovate compared to those relying on a single type of knowledge (Tödtling $\&$ Grillitsch, 2015). Again, this has implications for regional approaches to innovation, as the dominant innovation mode will determine the approach.

The second building block of the CRA relates to the type of RIS. Narrowly conceptualised, a RIS is made up of two subsystems: the knowledge production and the knowledge exploitation structures (Asheim et al., 2015). While the knowledge production structure is made up of university and $R \& D$ organisations in the region, the knowledge exploitation structure consists of firms exploiting the knowledge produced. This narrow conceptualisation emphasises that the STI type of innovation is more likely to occur in metropolitan regions, where firms need to be in contact with advanced research institutions.

The CRA advocates a broader definition of the RIS which include all the actors and activities affecting learning and innovation in the region. In addition to universities and R\&D institutes, the knowledge production structure is expanded to include higher education institutes (HEI), science parks, technical and vocational education institutes (Asheim, 2012). The broader view takes into account DUI and CCI modes, in addition to STI innovations. As such, contrary to the narrow view which is more inclined towards metropolitan regions, it applies both to metropolitan and non-metropolitan regions.

The third building block relates to the knowledge sourcing pattern of firms. It is now accepted that firms do not innovate in isolation (Fagerberg, Mowery, \& Nelson, 2005). The limitation of a local buzz approach, which is negative lock-in, has also been identified by Fitjar and Rodríguez-Pose (2011b). In the globalising knowledge economy, firms within regions rely not only on regional sources for knowledge, but increasingly seek complementary knowledge necessary for innovation at the national (Gertler \& Wolfe, 2006; Isaksen \& Kalsaas, 2009) and international levels (Laursen \& Salter, 2006; Tödtling \& Trippl, 2015). By doing so, they apply an open innovation model (Chesbrough, 2003). Understanding and facilitating the knowledge sourcing patterns of firms located in non-metropolitan regions is particularly important, as it helps update their innovative practices and prevent lock-ins.

The fourth building block, related variety, denotes the degree of cognitive relatedness between regional industries as well as the degree of similarity of inputs of production. For example, shipbuilding is cognitively related to the mining industry (Smith, 2005). Frenken et al. (2007) and Nooteboom, Van Haverbeke, 
Duysters, Gilsing, and van den Oord (2007) provide empirical evidence that a low cognitive distance (dissonance?) between regional industries leads to knowledge spillovers that bring about innovation and the formation of new firms through regional branching. High related variety among industries is primarily linked to metropolitan regions (Frenken et al., 2007). It increases their absorptive capacity and facilitates the diffusion of innovation between related industries (Boschma \& Iammarino, 2009; Giuliani \& Bell, 2005). Sourcing extraregional knowledge might also serve as a means to increase related variety in a region (Isaksen \& Karlsen, 2013).
As the four building blocks incorporate the most recent advances in regional innovation research, the CRA approach has been termed "state-of-the art" (Asheim, Moodysson, \& Tödtling, 2011). The four building blocks discussed above can be likened to inputs in the CRA approach, while continuous innovation is the output (Figure 1). A number of authors have applied the CRA approach to regional industries (Isaksen \& Karlsen, 2013; Karlsen et al., 2011) and have pointed out some of its shortcomings, as discussed in the next section.

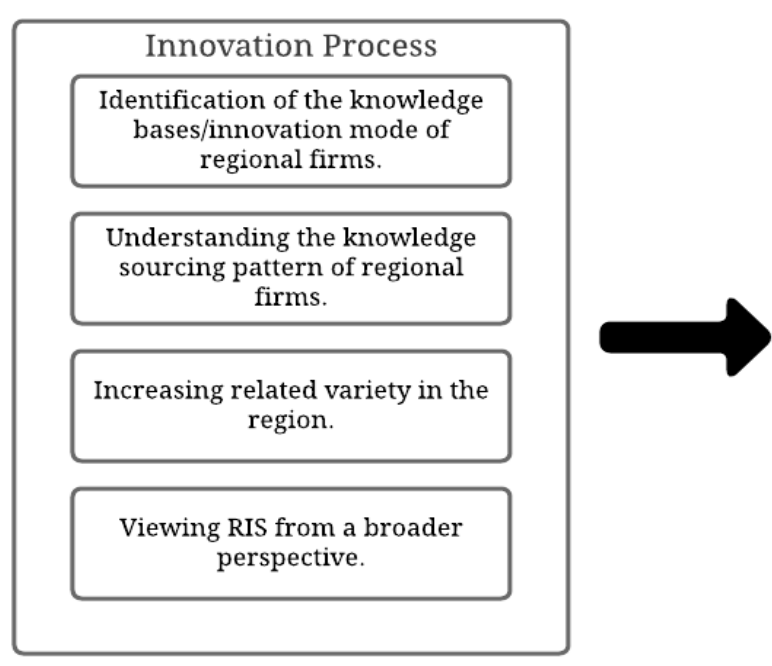

Input
Regional industrial competitiveness through continuous innovation

Figure 1: Schematic representation of the CRA approach

\section{Limitations of the CRA Approach}

As established above, the CRA framework is closely linked to clusters and RIS (narrow perspective) approaches, which are modelled on principles of agglomeration economies. The lack of critical mass of firms in non-metropolitan regions also means that they will be host to few cognitively related firms. However, related variety can brought into these regions by either sourcing extra-regional knowledge or attracting cognitively related firms through location incentives (Isaksen \& Karlsen, 2013).
According to Karlsen et al. (2011), the type of industry found at the regional level is important when applying the CRA. The current CRA framework, like clusters and RIS (narrow perspective) is primarily modelled on industries with an analytic knowledge base, linked to STI mode of innovation, and thus the linear model. According to Doloreux (2002), the linear model of innovation is sequenced as follows:

- Investments in R\&D;

- Product and process development; 
- Production;

- Marketing; and

- Diffusion.

Examples of industries characterised by this mode include biotechnology and nanotechnology (Asheim et al., 2011). Such industries require access to high-tech universities and $R \& D$ centres primarily located in metropolitan regions, and thus are mostly found in metropolitan regions. Not all industries however innovate linearly.

Industries characterised by a synthetic knowledge base, associated with the DUI mode of innovations, mainly innovate by modifying existing products and processes. $R \& D$ plays a lesser role as an industry with a STI mode and generally takes the form of applied research. Examples of industries with a synthetic knowledge base/DUI mode of innovation include plant engineering, specialised industrial machinery and shipbuilding (Asheim, Boschma, \& Coenen, 2011). Industries dominated by the DUI modes of innovation are most likely to be found in non-metropolitan regions (Isaksen, 2014).

More recently, Tödtling and Grillitsch (2015) have provided evidence that firms combining knowledge bases/innovation modes innovate more wherever they are located. They use the term combinatorial to designate businesses drawing simultaneously from analytic, synthetic or symbolic types of knowledge, from the STI and DUI modes of innovation, or sourcing knowledge from different spatial context (regional, national or international). Isaksen and Karlsen (2013) also contend that focusing on combinatorial knowledge bases/innovation modes is key when applying the CRA to non-metropolitan regions. This is important, as it allows firms located in these regions to supplement their predominantly synthetic type of knowledge and DUI mode of innovation with the analytic type of knowledge, the STI mode of innovation as well as extraregional knowledge. Such combinations might foster innovation in non-metropolitan firms (Tödtling \& Grillitsch, 2015).
According to Isaksen and Karlsen (2013), the CRA approach 'does not really address the firm level'. They argue that sourcing extraregional knowledge without the necessary internal competences will have little effect on firms' innovation activities. This is more relevant for non-metropolitan regions where firms are mostly SMEs (Flåten et al., 2015). This lack of focus of the CRA approach on the firm level can be explained by its strong links to the narrow view of the RIS approach. Asheim et al. (2015) have argued that the RIS approach, a major source of inspiration of the CRA approach 'is somewhat blunt as a tool for understanding the organisation of innovation from the perspective of the actors'. Actors refers to organisations and individuals, the RIS being primarily concerned with the macro and meso levels of institutions and social systems respectively (Asheim et al., 2015).

Focusing on the firm level is more relevant for businesses located in non-metropolitan regions, as it has been empirically proven by Huggins and Johnston (2009) and Tödtling and Trippl (2015) that access to extra-regional knowledge enhances the innovative performance of firms in non-metropolitan regions. In their study of innovation of the ICT sector in Austrian regions,

Tödtling and Grillitsch (2015) found a strong relationship between the firms' internal knowledge competencies and their ability to absorb extra-regional knowledge. The findings are in line with the literature on absorptive capacity. Similarly, Hewitt-Dundas and Roper (2011) and Pelkonen and Nieminen (2016) concur that efforts to increase the innovative performance of firms in non-metropolitan regions by facilitating access to extra-regional knowledge and publicly funded R\&D activities were constrained by their absorptive capacity. Likewise, Capello and Lenzi (2013,) argue that: 
The condition for a region to acquire knowledge from outside its boundaries is territorial receptivity, broadly defined as the capacity of the region to interpret and use external knowledge to achieve complementary research and science advances, more generally the absorptive capacity of a region à la Cohen and Levinthal (1990).

Absorptive capacity can be thought of as 'the ability of a firm to recognise the value of new, external information, assimilate it and apply to commercial ends' (Cohen \& Levinthal, 1990). It impacts greatly on a firms' internal innovative capabilities, such as their technology absorptive capacity and their technological innovation capabilities (Spithoven, 2011; Yam, et al., 2011). Sternberg and Arndt (2001) also provide convincing evidence that firmspecific determinants of innovation are more important than either region-specific or external factors. In relation to the maritime industry in non-metropolitan regions, increasing the absorptive capacity of maritime firms, which are predominantly SMEs will pave the way for sourcing relevant extra-regional knowledge that can be utilised for innovation.

It can be inferred from the above limitations that the CRA framework as initially proposed needs to be reconceptualised if it is to be used as tool for analysing and promoting innovation in non-metropolitan regions. Such reformulation will pave the way for its application in the maritime context, as current approaches have so far led to marginal results. The next section presents a reformulated CRA framework for metropolitan regions.

\section{A Proposed Reconceptualisation Of The Cra Approach For Non-Metropolitan Regions}

Isaksen and Karlsen (2013) argue that applying the CRA approach in non-metropolitan regions requires:

- A greater focus on the innovative capabilities of firms;
- Less emphasis on the endogenous capacity of RISs, which implies acquiring relevant knowledge for innovation from extra-regional sources; and

- Applying a combinatorial knowledge base approach.

Sourcing extra-regional knowledge is relevant only if firms have the capabilities to utilise that knowledge. Combining knowledge bases equally results in having the competencies to use the analytic type of knowledge for innovation. This paper therefore argues for the inclusion of a fifth building block in the CRA framework dealing with firms' internal innovative capabilities, since they greatly influence their capacity to exploit extra-regional knowledge, and innovate (Tödtling \& Grillitsch, 2015). In their study on the effectiveness of a (maritime) RIS approach to regional competitiveness through innovation, Melançon and Doloreux (2013), noted that the limited results achieved by the supply of innovation support organisation were due partly to the "limited absorptive capacity of regional maritime firms". This finding reiterates the fact that addressing the absorptive capacity is a key issue for maritime firms located in nonmetropolitan regions.

Isaksen and Karlsen (2013) however, only made suggestions regarding the inputs of the CRA approach. The output, continuous innovation remains broad. This paper contends that specifying the types of innovations promoted through the CRA approach is equally important. The CRA framework, clusters and RIS, are primarily modelled on industries where the linear mode of innovation dominates. The linear model of innovation is closely linked to radical innovations, which are innovations new to the industry or new to the world.

Firms dominated by the DUI mode innovate however mainly incrementally, that is by modifying existing products and processes. Radical and incremental innovations are however biased towards manufacturing, which has dominated innovation research (Carlborg, et al,. 2014; Gallouj \& Weinstein, 1997). The 
dominance of the world economy by the service sector has led to the increased recognition of service innovation (Mention, 2011). There is a consensus in the innovation literature that a Schumpeterian perspective should be adopted in innovation studies (Tödtling \& Grillitsch, 2014). It recognises four types of innovations (radical, incremental, organisational and marketing innovations), paving the way for the inclusion of both manufacturing and service firms in innovation surveys (OECD, 2005).

The maritime industry has a multi-sectorial knowledge base including both manufacturing and service firms. While a sector like maritime technology is R\&D driven (analytic knowledge base, thus radical innovations), shipbuilding and maritime equipment manufacturing are less R\&D driven and characterised by a synthetic knowledge base, thus dominated by incremental innovations. AMPS and the port sector on the other hand are more likely to introduce organisational and marketing innovations. A Schumpeterian perspective to innovation however allows for the inclusion of both types of firms in the same survey. This is reflected in Doloreux $(2006 ; 2008)$ studies on the innovative activities of maritime firms in non-metropolitan Canada (QCrs in particular), where all the four types of innovations were identified. In these studies, most maritime firms were engaged neither in intra, nor in extra-regional knowledge sourcing. As already explained, this might limit their innovative potentials, as access to knowledge and the ability to utilise knowledge sources elsewhere is key to firms' innovative capacity.

Taking into account the deficiencies of the current CRA approach and in line of the above suggestions, this paper proposes a reformulation as shown in Figure 2. Compared to the initially proposed CRA approach, made up of four building blocks, the reconceptualised framework in this paper has a fifth block relating to firm's internal innovative capabilities. The rationale for the inclusion of this block has been extensively discussed above and relate to the ability of firms to assimilate and convert new knowledge into innovation. Similarly, the reconceptualised framework clearly identifies the types of innovations to promote, making it easier for evaluation purpose.

In terms of its inputs, they differ substantially from those of other studies on innovation in the maritime industry at the non-metropolitan level. The innovation inputs for maritime firms identified by Doloreux (2006, 2008), (Doloreux \& Melançon, 2008) and Pinto et al. (2015) include: internal $\mathrm{R} \& \mathrm{D}$, employee training, the acquisition of external $R \& D$, the acquisition of machinery and equipment, collaboration with regional or extra-regional firms/institutions for the purpose of innovation and the acquisition of external competences. These inputs can be allocated to different building blocks of the framework proposed in this paper. For example, collaboration with regional or extraregional firms/institutions, the acquisition of external $R \& D$ and competences relate to open innovation, the intensity of internal $R \& D$ relates to the knowledge base/innovation mode and employee training relates to firm's internal innovative capabilities.

In terms of its outputs, they are similar to those identified in other maritime studies such as Jenssen and Randøy (2002), Doloreux (2006; 2008) and, Doloreux and Melançon (2008). In accordance with these authors, maritime organisations like other type of firms can innovate by being first in the world to introduce a product, an operational or organisational process, a service, or a marketing method. They can also innovate by introducing a product, a service an operational/organisation process or a marketing method developed by other firms. The term 'new' in Figure 2 therefore relates to innovations new to the world or to the firm. Finally, firms can innovate by significantly improving their existing products, services, operational or organisational processes and marketing methods.

The reconceptualised framework is, therefore, clearly relevant to the maritime industry and might help to establish a clear relationship between innovation inputs and 


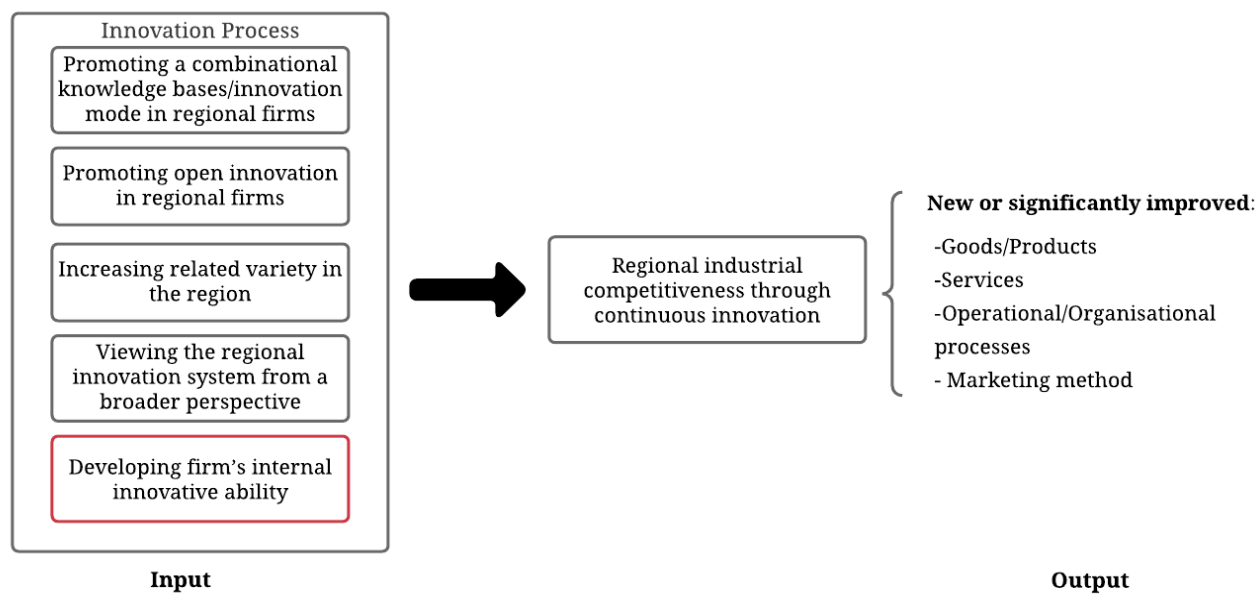

Figure 2: Reconceptualised CRA approach for non-metropolitan regions

outputs. Such a link is still missing in current studies on regional innovation in the maritime industry, especially in the context of nonmetropolitan regions.

\section{Conclusion and Direction for Future Maritime Research}

This paper centred on conceptual tools policymakers have relied upon to promote regional innovation in the maritime industry, in the context of non-metropolitan regions. The principal gap identified in the current literature is that no clear alternative is provided, although there is a consensus that current approaches have yielded little results for maritime firms located in non-metropolitan regions. Building on the limitations of the most influential approaches to regional innovation, this paper has provided such an approach, namely: the CRA approach to regional innovation in the maritime industry.

In addition to addressing the identified gap, this paper introduces the CRA approach to the maritime environment. It has already been found useful when applied to other industries in its original form. Being a step ahead (as built on their limitations) of clusters and RIS approaches (already well-established to the maritime environment), the CRA approach provides maritime scholars with a new theoretical lens through which innovation the maritime industry can be analysed. Thus, paving the way for future research on innovation in the maritime industry in general, and on the right approach to promoting innovation in maritime firms located in non-metropolitan regions.

The topic of innovation and its geography has received little attention from maritime scholars, with the few extant studies mainly focusing on the national level. Maritime businesses however do not exist in abstract spaces, but often fall within one of the types of regions identified in this paper. They are thus influenced by regional characteristics. Moreover, innovation is the only viable alternative for maritime or other firms if they are to survive in a globalising knowledge economy. As established in this paper, innovation does not occur automatically, even when all the prerequisites are in place. It needs to be pro-actively promoted, especially in nonmetropolitan regions facing greater barriers to innovation. The reconceptualised CRA approach proposed by this paper may assist policymakers in regions other than the 'happy few' (Asheim \& Coenen, 2005). It will be instrumental to understand the knowledge sourcing patterns of maritime firms located in non-metropolitan regions, the role played by the region in their innovative activities, the critical knowledge they use to innovate, as well as whether the presence 
of cognitively related activities in the regions has an influence on their innovation activities. Such an understanding is critical when planning for competitiveness through innovation at the regional level.

As this paper is conceptual on nature, the reformulated framework needs to be scientifically and empirically tested, to assess its true value. Empirical studies are therefore needed to qualitatively assess and quantitatively measure the impact of the individual and collective building blocks of the CRA approach on firms' innovation activities.

Though developed with the intent of application in the broader maritime in regional Australia where a recent study by (Sakalayen, 2014) narrowly focused on regional ports, the approach is generic in nature. Thus, providing a wide range of application across different industries.

\section{Acknowledgements}

I would like to thank the two anonymous reviewers who provided feedback on an earlier version of this manuscript.

\section{References}

Acs, J. Z. (2002). Innovation and the growth of cities. Northampton, MA: Edward Elgar.

Asheim, B. (2012). Innovation and the role of diversity in the globalising knowledge economy. In H. Garmann Johnsen \& R. Ennals (Eds.), Creating collaborative advanatage: Innovation and knowledge creation in regional economies (pp. 141149). England: Gower publishing limited.

Asheim, B., Boschma, R., \& Cooke, P. (2011). Constructing regional advantage: Platform policies based on related variety and differentiated knowledge bases. Regional Studies, 45(7), 893-904.
Asheim, B., \& Coenen, L. (2005). Knowledge bases and regional innovation systems: Comparing Nordic clusters. Research policy, 34(8), 1173-1190. doi:10.1016/j. respol.2005.03.013

Asheim, B., Coenen, L., \& Moodysson, J. (2015). Methods and applications of regional innovation systems analysis. In C. Karlsson, M. Andersson, \& T. Norman (Eds.), Handbook of Research Methods and Applications in Economic Geography (pp. 272-290). Cheltenham, UK: Edward Edgar publishing limited.

Asheim, B., Coenen, L., Moodysson, J., \& Vang, J. (2007). Constructing knowledgebased regional advantage: Implications for regional innovation policy. International Journal of Entrepreneurship and Innovation Management, 7(2-5), 140-155.

Asheim, B., Moodysson, J., \& Tödtling, F. (2011). Constructing regional advantage: Towards state-of-the-art regional Innovation system policies in Europe? European Planning Studies, 19(7), 1133-1139.

Bass, H.-H., \& Ernst-Siebert, R. (2007). SME in Germany's maritime industry: innovation, internationalisation and employment. Int. J. Globalisation and Small Business, 2(1), 19.

Bathelt, H., Malmberg, A., \& Maskell, P. (2004). Clusters and knowledge: Local buzz, global pipelines and the process of knowledge creation. Progress in human geography, 28(1), 31-56.

Benito, G. R., Berger, E., De la Forest, M., \& Shum, J. (2003). A cluster analysis of the maritime sector in Norway. International Journal of Transport Management, 1(4), 203-215.

Boschma, R. (2005). Proximity and innovation: a critical assessment. Regional Studies, 39(1), 61-74. 
Boschma, R. (2013). The emergence of new industries at the regional level in Spain: A proximity approach based on product relatedness new industries and relatedness in regions. Economic geography, 89(1), 2951. doi:10.1111/j.1944-8287.2012.01170.x

Boschma, R. (2014). Constructing regional advantage and smart specialisation: Comparison of two European policy concepts. Scienze Regionali, 13(1), 51-68.

Boschma, R., \& Iammarino, S. (2009). Related variety, trade linkages, and regional growth in Italy. Economic geography, 85(3), 289311.

Brett, V., \& Roe, M. (2010). The potential for the clustering of the maritime transport sector in the Greater Dublin Region. Maritime Policy \& Management, 37(1), 1-16.

Camagni, R. (2002). On the concept of territorial competitiveness: Sound or misleading? Urban studies, 39(13), 2395-2411.

Capello, R., \& Lenzi, C. (2013). Territorial patterns of innovation: A taxonomy of innovative regions in Europe. The Annals of regionalscience, 51(1), 119-154. doi:10.1007/ s00168-012-0539-8

Carlborg, P., Kindström, D., \& Kowalkowski, C. (2014). The evolution of service innovation research: A critical review and synthesis. The Service Industries Journal, 34(5), 373398.

Carlsson, B. (2007). Innovation systems: a survey of the literature from a Schumpeterian perspective. In H. Hanusch \& A. Pyka (Eds.), Elgar companion to neoSchumpeterian economics (pp. 857-871). Cheltenham, UK: Edward Elgar publishing limited.

Chang, Y.-C. (2011). Maritime clusters: What can be learnt from the South West of England. Ocean \& Coastal Management, 54(6), 488-494.
Chesbrough, H. (2003). Open innovation: The new imperative for creating and profiting from technology. Boston: Harvard Business School Press.

Coe, N. M., Hess, M., Yeung, H. W. c., Dicken, P., \& Henderson, J. (2004). 'Globalizing'regional development: a global production networks perspective. Transactions of the Institute of British Geographers, 29(4), 468-484.

Cohen, W. M., \& Levinthal, D. A. (1990). Absorptive capacity: A new perspective on learning and innovation. Administrative Science Quarterly, 35(1), 128-152.

Cooke, P., Gomez Uranga, M., \& Etxebarria, G. (1997). Regional innovation systems: Institutional and organisational dimensions. Research policy, 26(4-5), 475-491. doi:http:// dx.doi.org/10.1016/S0048-7333(97)00025-5

de Langen, P. (2002). Clustering and performance: the case of maritime clustering in the Netherlands. Maritime Policy \& Management, 29(3), 209-221.

Ding, J., Ge, X., \& Casey, R. (2014). "Blue competition" in China: Current situation and challenges. Marine Policy, 44, 351359. doi:http://dx.doi.org/10.1016/j. marpol.2013.09.028

Djoumessi, A., Chen, S.-L., \& Cahoon, S. (2019). Factors influencing innovation in maritime clusters: An empirical study from Australia. Marine Policy, 108, 103558.

Doloreux, D. (2002). Regional systems of innovation in Canada: A comparative study. $(\mathrm{PhD})$, University of Waterloo, Waterloo.

Doloreux, D. (2006). Understanding regional innovation in the maritime industry: an empirical analysis. International Journal of Innovation and Technology Management, 3(02), 189-207.

Doloreux, D., \& Melançon, Y. (2008). On the dynamics of innovation in Quebec's coastal maritime industry. Technovation, 28(4), 231-243. doi:http://dx.doi.org/10.1016/j. technovation.2007.10.006 
Doloreux, D., \& Melançon, Y. (2009). Innovation-support organizations in the marine science and technology industry: The case of Quebec's coastal region in Canada. Marine Policy, 33(1), 90-100.

Doloreux, D., \& Shearmur, R. (2006). Regional development in sparsely populated areas: The case of Quebec's missing maritime cluster. Canadian Journal of Regional Science, 29(2), 195-220.

Doloreux, D., \& Shearmur, R. (2009). Maritime clusters in diverse regional contexts: The case of Canada. Marine Policy, 33(3), 520527.

Doloreux, D., Shearmur, R., \& Figueiredo, D. (2016). Québec' coastal maritime cluster: Its impact on regional economic development, 2001-2011. Marine Policy, 71, 201-209. doi:http://dx.doi.org/10.1016/j. marpol.2016.05.028

European Commission. (2006). Constructing regional advantage. Principles perspectives - policies. Retrieved from Brussels:

Fagerberg, J., Mowery, D., \& Nelson, R. (2005). The Oxford hanbook of innovation. Oxford: Oxford university press.

Fitjar, R. D., \& Rodríguez-Pose, A. (2011a). Innovating in the periphery: firms, values and innovation in Southwest Norway. European Planning Studies, 19(4), 555574.

Fitjar, R. D., \& Rodríguez-Pose, A. (2011b). When local interaction does not suffice: Sources of firm innovation in urban Norway. Environment and planning A, 43(6), 12481267.

Flåten, B.-T., Isaksen, A., \& Karlsen, J. (2015). Competitive firms in thin regions in Norway: The importance of workplace learning. Norsk Geografisk TidsskriftNorwegian Journal of Geography, 69(2), 102-111.
Flitsch, V., Herz, N., Wolff, J., \& Baird, A. J. (2014). Maritime policy in the North Sea region: Application of the cluster approach. Maritime Economics \& Logistics, 16(4), 484-500. doi:10.1057/mel.2014.12

Florida, R., Gulden, T., \& Mellander, C. (2008). The rise of the mega-region. Cambridge Journal of Regions, Economy and Society, 1(3), 459-476.

Frenken, K., Van Oort, F., \& Verburg, T. (2007). Related variety, unrelated variety and regional economic growth. Regional Studies, 41(5), 685. doi:10.1080/00343400601120296

Friedman, T. L. (2005). The world is flat: A brief story of the twenty first century. New York: Farrar, Straus and Giroux.

Gallouj, F., \& Weinstein, O. (1997). Innovation in services. Research policy, 26(4-5), 537556. doi:http://dx.doi.org/10.1016/S00487333(97)00030-9

Gertler, M., \& Wolfe, D. (2006). Spaces of knowledge flows: Clusters in the global context. In B. Asheim, P. Cooke, \& R. Martin (Eds.), Clusters and regional development: Critical reflections and explorations (pp. 218-235). London: Routledge.

Giuliani, E., \& Bell, M. (2005). The microdeterminants of meso-level learning and innovation: evidence from a Chilean wine cluster. Research policy, 34(1), 47-68. doi:http://dx.doi.org/10.1016/j. respol.2004.10.008

Glaeser, E., Kallal, H. D., Scheinkman, J. A., \& Shleifer, A. (1992). Growth in cities. Hall, P. V., \& Jacobs, W. (2012). Why are maritime ports (still) urban, and why should policy-makers care?. Maritime Policy \& Management, 39(2), 189-206.

Hansen, T., \& Winther, L. (2011). Innovation, regional development and relations between high-and low-tech industries. European Urban and Regional Studies, 18(3), 321339. 
Hewitt-Dundas, N., \& Roper, S. (2011). Creating advantage in peripheral regions: The role of publicly funded R\&D centres. Research policy, 40(6), 832-841. doi:10.1016/j. respol.2011.03.005

Huggins, R., \& Johnston, A. (2009). Knowledge networks in an uncompetitive region: SME innovation and growth. Growth and change, $40(2), \quad 227-259$. doi: $10.1111 / \mathrm{j} .1468$ 2257.2009.00474.x

Isaksen, A. (2009). Innovation dynamics of global competitive regional clusters: The case of the Norwegian centres of expertise. Regional Studies, 43(9), 1155-1166. doi:10.1080/00343400802094969

Isaksen, A. (2014). Industrial development in thin regions: trapped in path extension?. Journal of economic geography, 15(3), 585600.

Isaksen, A., \& Kalsaas, B. T. (2009). Suppliers and strategies for upgrading in global production networks: the case of a supplier to the global automotive industry in a highcost location. European Planning Studies, 17(4), 569-585.

Isaksen, A., \& Karlsen, J. (2012). What is regional in regional clusters? The case of the globally oriented oil and gas cluster in Agder, Norway. Industry and Innovation, 19(3), 249-263.

Isaksen, A., \& Karlsen, J. (2013). Can small regions construct regional advantages? The case of four Norwegian regions. European Urban and Regional Studies, 20(2), 243257.

Isaksen, A., \& Sæther, B. (2015). Innovation in small regions. Norsk Geografisk TidsskriftNorwegian Journal of Geography, 69(2), 65-66.

Jacobs, W., Ducruet, C., \& de Langen, P. (2010). Integrating world cities into production networks: the case of port cities. Global Networks, 10(1), 92-113. doi:10.1111/ j.1471-0374.2010.00276.x
Jacobs, W., Koster, H., \& Hall, P. (2011). The location and global network structure of maritime advanced producer services. Urban studies, 48(13), 2749-2769.

Jensen, M. B., Johnson, B., Lorenz, E., \& Lundvall, B. Å. (2007). Forms of knowledge and modes of innovation. Research policy, 36(5), 680-693. doi:http://dx.doi. org/10.1016/j.respol.2007.01.006

Jenssen, J. I., \& Randøy, T. (2002). Factors that promote innovation in shipping companies. Maritime Policy \& Management, 29(2), 119-133.

Karlsen, J., Isaksen, A., \& Spilling, O. (2011). The challenge of constructing regional advantages in peripheral areas: The case of marine biotechnology in Tromsø, Norway. Entrepreneurship and Regional Development, 23(3-4), 235-257. doi:10.1080/08985620903233945

Laestadius, S. (1998). Technology level, knowledge formation, and industrial competence in paper manufacturing. In G. Eliasson, C. Green, \& C. R. Mccann (Eds.), Microfoundations of economic growth: A Schumpeterian perspective (pp. 212-226). (Ann Arbour: University of Michigan Press.

Laursen, K., \& Salter, A. (2006). Open for innovation: the role of openness in explaining innovation performance among UK manufacturing firms. Strategic management journal, 27(2), 131-150.

Lundvall, B. Å. (2008). National innovation systems-analytical concept and development tool. Industry and Innovation, 14(1), 95119.

Makkonen, T., Inkinen, T., \& Saarni, J. (2013). Innovation types in the Finnish maritime cluster. WMU Journal of Maritime Affairs, $12(1), 1-15$.

Malmberg, A., \& Maskell, P. (2002). The elusive concept of localization economies: towards a knowledge-based theory of spatial clustering. Environment and planning $A$, 34(3), 429-450. 
Malmberg, A., \& Maskell, P. (2006). Localized learning revisited. Growth and change, 37(1), 1-18.

Manniche, J., Moodysson, J., \& Testa, S. (2016). Combinatorial Knowledge Bases: An Integrative and Dynamic Approach to Innovation Studies. Economic geography, $1-20$.

Martin, R., \& Moodysson, J. (2011). Comparing knowledge bases: on the geography and organization of knowledge sourcing in the regional innovation system of Scania, Sweden. European Urban and Regional Studies, 20(2), 170-187.

Martin, R., \& Trippl, M. (2014). System failures, knowledge kases and regional innovation policies. DISP, 50(1), 24-32. doi:10.1080/0 2513625.2014.926722

Maskell, P., \& Malmberg, A. (1999). Localised learning and industrial competitiveness. Cambridge Journal of Economics, 23(2), 167-185.

McCann, P. (2008). Globalization and economic geography: the world is curved, not flat. Cambridge Journal of Regions, Economy and Society, 1(3), 351-370.

Melançon, Y. (2011). Soutenir l'innovation dans la péripherie le cas du soutien a l'innovation maritime au Quebec maritime. (PhD PhD), Université du Québec a Rimouski, Canada.

Melançon, Y., \& Doloreux, D. (2013). Developing a knowledge infrastructure to foster regional innovation in the periphery: a study from Quebec's coastal region in Canada. Regional Studies, 47(9), 15551572.

Mention, A.-L. (2011). Co-operation and coopetition as open innovation practices in the service sector: Which influence on innovation novelty? Technovation, 31(1), 44-53.

Merk, O. (2013). The competitiveness of global port-cities: Synthesis report (2073-7009). Retrieved from Paris:
Merk, O., \& Dang, T.-T.(2013). The Effectiveness of Port-City Policies: A COMPARATIVE $A P P R O A C H$. Retrieved from Paris:

Monteiro, P. (2015). General Insights of the Portuguese Maritime Economy and Particularly of the Algarve Region: Contributing Towards a Strategic Vision. Journal of Maritime Research, 11(1).

Moreno, R., Paci, R., \& Usai, S. (2005). Spatial spillovers and innovation activity in European regions. Environment and planning A, 37(10), 1793-1812.

Morrissey, K., \& O’Donoghue, C. (2013). The potential for an Irish maritime transportation cluster: An input-output analysis. Ocean \& Coastal Management, 71, 305-313.

Morrissey, K., O’Donoghue, C., \& Farrell, N. (2014). The local impact of the marine sector in Ireland: a spatial microsimulation analysis. Spatial Economic Analysis, 9(1), 31-50.

Nooteboom, B., Van Haverbeke, W., Duysters, G., Gilsing, V., \& van den Oord, A. (2007). Optimal cognitive distance and absorptive capacity. Research policy, 36(7), 10161034. doi:http://dx.doi.org/10.1016/j. respol.2007.04.003

O'Riain, S. (2011). Globalisation and regional development. In A. Pike, A. RodríguezPose, \& J. Tomaney (Eds.), Handbook of local and regional development. New York: Routledge.

OECD. (2005). Oslo Manual: Proposed guidelines for collecting and interpreting innovation data (9264013083). Retrieved from Paris:

Ortega, C., Nogueira, C., \& Pinto, H. (2013). Sea and Littoral Localities' Economy: Exploring Potentialities for a Maritime Cluster-An Integrated Analysis of Huelva, Spain and Algarve, Portugal. Journal of Maritime Research, 10(2), 35-42. 
Othman, M. R., Bruce, G. J., \& Hamid, S. A. (2011). The strength of Malaysian maritime cluster: The development of maritime policy. Ocean \& Coastal Management, 54(8), 557-568.

Pelkonen, A., \& Nieminen, M. (2016). How beneficial is a knowledge-based development strategy for peripheral regions? A case study. European Planning Studies, 24(2), 364-386.

Pike, A., Rodríguez-Pose, A., \& Tomaney, J. (2006). Local and regional development (A. Pike, A. Rodríguez-Pose, \& J. Tomaney Eds.). London: Routledge.

Pinto, H., \& Cruz, A. R. (2012). Structuring a Knowledge-based Maritime Cluster: Contributions of Network Analysis in a Tourism Region/Estructuración de un Clúster Marítimo basado en Conocimiento: Aportaciones del análisis de redes en una región de turismo. Revista de Estudios Regionales(95), 101-118.

Pinto, H., Cruz, A. R., \& Combe, C. (2015). Cooperation and the emergence of maritime clusters in the Atlantic: Analysis and implications of innovation and human capital for blue growth. Marine Policy, 57, 167-177. doi:10.1016/j.marpol.2015.03.029

Porter, M. (1990). The competitive advantage of nations. London: Macmillan.

Porter, M. (1998). Clusters and the new economics of competition. Harvard Business Review, 76, 77-90.

Porter, M. (2000). Location, competition, and economic development: Local clusters in a global economy. Economic Development Quarterly, 14(1), 15-34.

Rodríguez-Pose, A., \& Fitjar, R. D. (2013). Buzz, archipelago economies and the future of intermediate and peripheral areas in a spiky world. European Planning Studies, 21(3), 355-372.
Sakalayen, Q. M. (2014). The Strategic role of Australian regional ports in regional development. ( $\mathrm{PhD} \mathrm{PhD} \mathrm{Thesis),} \mathrm{University}$ of Tasmania, Australia.

Salvador, R. (2013). Maritime clusters evolution: the (not so strange) case of the Portuguese maritime cluster. Journal of Maritime Research, 11(1), 53-59.

Shearmur, R. (2012). Are cities the font of innovation? A critical review of the literature on cities and innovation. Cities, 29, S9-S18.

Shinohara, M. (2010). Maritime cluster of Japan: implications for the cluster formation policies. Maritime Policy and Management, 37(4), 377-399.

Smith, K. (2005). Measuring innovation. In J. Fagerberg, R. Nelson, \& D. Mowery (Eds.), The Oxford handbook of innovation (pp. 148-177). Oxford: Oxford university press.

Spithoven, A., Clarysse, B., \& Knockaert, M. (2011). Building absorptive capacity to organise inbound open innovation in traditional industries. Technovation, 31(1), 10-21. doi:http://dx.doi.org/10.1016/j. technovation.2010.10.003

Sternberg, R., \& Arndt, O. (2001). The firm or the region: what determines the innovation behavior of European firms? Economic geography, 77(4), 364-382.

Tödtling, F., \& Grillitsch, M. (2014). Types of innovation, competencies of firms, and external knowledge sourcing-Findings from selected sectors and regions of Europe. Journal of the knowledge economy, 5(2), 330-356. doi:http://dx.doi.org/10.1007/ s13132-012-0139-y

Tödtling, F., \& Grillitsch, M. (2015). Does Combinatorial Knowledge Lead to a Better Innovation Performance of Firms? European Planning Studies, 23(9), 17411758.

Tödtling, F., \& Trippl, M. (2005). One size fits all? Towards a differentiated regional innovation policy approach. Research policy, 34(8), 1203-1219. 
Tödtling, F., \& Trippl, M. (2015). How do firms acquire knowledge in different sectoral and regional contexts? Retrieved from Lund, Sweden:

Varga, A. (2000). Local academic knowledge transfers and the concentration of economic activity. Journal of regional science, 40(2), 289-309. doi:10.1111/0022-4146.00175

Verhetsel, A., \& Sel, S. (2009). World maritime cities: From which cities do container shipping companies make decisions? Transport Policy, 16(5), 240-250.
Yam, R. C. M., Lo, W., Tang, E. P. Y., \& Lau, A. K. W. (2011). Analysis of sources of innovation, technological innovation capabilities, and performance: An empirical study of Hong Kong manufacturing industries. Research policy, 40(3), 391-402. doi:http://dx.doi. org/10.1016/j.respol.2010.10.013

Yan, X., Yan, L., Yao, X.-L., \& Liao, M. (2015). The marine industrial competitiveness of blue economic regions in China. Marine Policy, 62, 153-160. doi:http://dx.doi.org/10.1016/j. marpol.2015.09.015 